\title{
The Library of Congress and the Other Scholarly Libraries of the Nation'
}

\author{
Mr. Clapp is assistant librarian, Library \\ of Congress.
}

$I^{\mathrm{N}}$ ORDER to supply a text for what follows, I am going to quote, with permission, from the letter which John E. Burchard, the chairman of your program committee, wrote to Dr. Evans last September, in which he suggested the topic for this discussion.

You, of course, also are well aware of the uncertainty which exists in the minds of the directors of the private library resources of the nation and especially of the East as to the full ambitions of the principal Federal collections and especially those in Washington, as to the extent to which the ambitions are likely to be realized and as to the bearing which these things have on the responsibilities of the private reference collections and on the relations of the private libraries to the Federal ones. I have felt that discussion of this subject has always been something less than forthright and that it is perhaps time that we got down to brass tacks, if this can be dared.

I can give an immediate and categorical assurance on one or two of the points raised in this formulation of the topic. I can assure you that we at the Library of Congress have no desire to hide any of our pretensions or ambitions; we have every desire that discussion of any subject in which the Library of Congress is involved should be completely forthright; and we are prepared at any time to get down to brass tacks.

1 Abridgement of a paper presented at the Conference of Eastern College Librarians, Columbia University, Nov. $29,1947$.
Actually, however, I should remind you that this is not a new question. At least since 1879 , when the A.L.A., by official action recognized "the importance of providing the National Library of Congress with new and convenient quarters, worthy of its national importance," ${ }^{2}$ the question of the place of the Library of Congress in the national library economy has come up at frequent intervals. The question was thoroughly canvassed before a committee of Congress in 1896 , when the transfer of the library from the Capitol to the then new building was under contemplation. Herbert Putnam's Waukesha address is still a fairly comprehensive statement on the subject; and Archibald MacLeish touched on the salient points of the question in his annual report for 1940. Finally, the question has been considered in detail in the report of the Library of Congress Planning Committee as recently as last March.

There are really two kinds of ambitions involved here: the ambitions which the $\mathrm{Li}$ brary of Congress has for itself, and the ambitions which the library world has for it. These are not always identical, nor have they always been completely reconciled. For example: it has long been the officially adopted view of the organized American library world that the Library of Congress should possess a copy of every publication which appears in the United States, and this is an ambition which is cultivatedwith some reservations-by the library it-

\footnotetext{
${ }^{2}$ Library Journal I: 303 , July-August I 879 .
} 
self. But when, as it does with particular categories, the library refuses to lend certain materials in interlibrary loan, the fruit of the attainment of this ambition is denied to many of those who supported it. Again, with printed catalog cards: the library's ambition is, of course, to get its own books cataloged; and the card distribution system rests legally upon the theory that they are a by-product of the library's domestic operations. On the other hand, the equally natural ambition of other libraries is to have the printed cards serve their uses as fully as possible. Thus, we have had to ask ourselves, for whom are we cataloging-for ourselves or for other libraries? But instances of such oppositions are not too numerous, nor do I believe them to be unresolvable.

At this point I want to make a general observation, the implications of which ought to be interesting, but which I cannot here pursue to their ultimate conclusion. This is that the functions and responsibilities of the Library of Congress derive from its collections, rather than the other way about.

\section{First Collections-Then Functions}

Those of you who have read David Mearns' The Story up to Now in Dr. Evans' 1946 report (also issued as a separate) know that the Library of Congress was never even really established; it became. We trace our foundation from the law of Apr. 24, I800; but that law did not mention a Library of Congress; it merely authorized the purchase of a collection of books "for the use of both Houses of Congress and the members thereof ;" and the name "Library of Congress" was not mentioned in legislation until five years later. However - and this is the important thing -as soon as the collection was organized, its functions were extended beyond the original restricted purpose ; and this is what has happened consistently ever since.

It was not until after the middle of the century, however, that the use of the library became a matter of general public concern. An act of 1846 had given the library a share in the deposits under the copyright laws. Finally, by an act of 1866 , the library became the depository of the twenty-year old library of the Smithsonian Institution, with its rich and continuing collections of scientific and other materials secured as the result of exchanges with academies and learned societies all over the world. It was logical that at that moment the service of the library should be extended still further; and the same act of $\mathrm{I} 866$ consequently provided that the "public shall have access ... for purposes of consultation on every ordinary weekday except during one month of the year, in the recess of Congress, when it may be closed for renovation." By this enactment the library, though it remained the Library of Congress, became genuinely a national library in the sense of public ownership and public access.

In 1870 responsibility for the performance of "all acts and duties required by law touching copyrights," was assigned to the Librarian of Congress, who thenceforth received, in compensation for the administrative burden, copies of every article registered for copyright, not only books, but also periodicals, picture-postcards, circus posters, and labels for cigar boxes and hair tonics, and, at a later date, motion pictures and designs.

It is obvious that these enactments, when enforced by an energetic librarian, could in a short time very radically affect the complexion of the collections. They did. The collections grew apace. And with their growth came insistence from the nation at large that they be made available for use. This insistence took form, for example, in 
President Hayes' message to Congress in December 1878 :

As this library is national in character, and must from the nature of the case increase even more rapidly in the future than in the past, it cannot be doubted that the people will sanction any wise expenditure to preserve it and to enlarge its usefulness.

Subsequent history has followed in a like course. You all know the story of the origin of the distribution of printed catalog cards. (It is summarized in the preface of the A.R.L.-Edwards Brothers I68-volume Catalog of Books Represented by Library of Congress Printed Cards.) A source of central cataloging had been the desideratum of the American library world at least since I 850 when Professor Jewett announced his plan for stereotype cataloging. Several methods were tried. One significant advance in practicability was contributed by the library of the Department of Agriculture. But the genuine-though perhaps not the final-solution to the problem was not discovered until a method was employed which utilized the operations of a library already receiving and cataloging for its own uses a large proportion of the very books in which libraries generally were interested. So it was with the national union catalog and with books for the adult blind and with state publications and state laws. The responsibility has followed the collections in almost every case; not preceded it.

I am inclined to think that this question -the question of what are the ambitions of the Library of Congress, the extent to which these ambitions are likely to be realized, and their bearing upon the private reference collections-may well be taken in three steps. The first of these would have to do with what I would like to differentiate, if that is altogether possible, as the purely local situation; the second with the relations which have grown up with other libraries throughout the country; and the third with the general question of what should be the functions of a national library.

\section{The Local Situation}

First, as to the local situation. Under this head I refer to the service which is required of the library by law or custom and which derives from the fact that it is established at the seat of government and is an agency of government. What does this situation require of the library? It requires, first, a general library service to Congress, and then a special legislative reference service which is spelt out carefully in substantive law enacted during the $79^{\text {th }}$ Congress-even to the extent of specifying the subjects in which the library shall have specialists, and the grade of those specialists. It requires the extension of the facilities of the collections to the agencies of the executive and the judiciary. It requires the further extension of these facilities to qualified members of the public. It requires, above all, that the collections be organized through indexes and otherwise; and several laws, chief of which is the Copyright Act, specifically require this.

What does this involve in the way of ambitions? Very simply, it is to live up to our legal obligations. But if we can do this, we shall have nearly won the whole battle, for it is exactly the product of the preparation for the local service which fits us to be of service beyond this boundary.

Our ambitions include, consequently, the development of cooperative enterprises which will relieve us, equally with others, of cost. Nevertheless, when all bibliographic assistance is accounted for, there is still a domestic operation which must be performed. The burden of work which now confronts us is more than we can efficiently carry in almost every department. 
Our estimates for 1947, which contemplated a doubling of the staff, included, it is true, certain new activities, but were for the most part based entirely upon actual work-loads in existing operations.

Specifically, the local situation involves certain very definite allocations of fields of responsibility among the federal libraries, and although the Library of Congress has not divested itself of its accumulations either in agriculture or medicine-for it finds considerable use of the collections in both fields in connection with its other collections-it makes no purchases in these fields beyond essential reference books. As all of you know who purchase L.C. cards, series providing the results of cataloging of a number of the other government libraries are represented therein. Our interest in this connection is in economy and efficiency of library service, and it is our belief that library service can be given most economically if there is one central collection, comprehensive within defined limits, supported by working or special collections in the various agencies or operating units. In this belief we are supported by the recommendations of the Library of Congress Planning Committee.

\section{The National Situation}

With respect to the national situationthe relation of the Library of Congress to the other libraries of the country-I reassert the principle which I have tried to establish: these relationships depend and must depend, not upon any primacy established by law, not upon any executive authority, but upon a capacity for service, which in turn depends historically upon the collections.

As many of you probably know, the Library of Congress has resisted any suggestions that it be equipped with an executive function. It was perhaps for this reason that Arundell Esdaille, in his volume on the National Libraries of the $W$ orld, ${ }^{3}$ failed to include, in the chapter on the Library of Congress, a section on "Place in a $\mathrm{Na}$ tional System" which he had incorporated into the chapter on almost every other national library.

It has been repeatedly pointed out that Congress would never have required two copies of every copyrighted publication solely for its own use, nor purchased great collections of Americana, of incunabula, of Russian books, or of the papers of the presidents exclusively for its own service; nor, finally, constructed buildings at great expense to house these collections solely for its own enjoyment. Obviously the benefits of these collections are intended for the entire nation. But how? Congress has ruled that the collections are to be made accessible to qualified members of the public; but beyond that Congress has not prescribed the details in any broad, over-all legislation. Congress, has, nevertheless, authorized or facilitated specific activities when they have been represented as in the national interest, such as interlibrary loans, the card distribution service, the union catalog and the photoduplication service, the service of books for the blind, as well as various publications including the L.C. classification schedules, the lists of subject-headings, the service in the decimal classification, the biennial Index to State Legislation, the Monthly Checklist of State Publications, calendars and checklists, and texts such as the Journals of the Continental Congress. Finally, the development of a number of specialist units in the library, some on a subject basis, some by area or language, and still others by the form of the material, makes provision for supplying, in response to inquiries, statements which are to a high degree authoritative regarding the content

s London, Grafton and Co., r934. p. v. 
and location of the literature of a particular subject.

\section{The Functions of a National Library}

I must press on to my third step: a consideration of what functions are appropriate to a national library. The American library world has been calling the Library of Congress the national library for some 70 years; yet nowhere have I found an actual content of meaning assigned to the term. Arundell Esdaille speaks of the national library as "that comparatively modern product;" he adds, "the idea of a national library has for over a century, and for longer still, if we consider it rightly, been expanding;" and he notes that the Abbé Bignon in Paris, Baron Korf in Moscow, Sir Anthony Panizzi in London, and Dr. Putnam in Washington each in his generation took some fresh and valuable element into the functions of a national library. "What their successors will do," he concludes, "we cannot foresee. The age of wireless, the gramaphone, the film and the microphotograph may change the whole face of libraries. We may at least be certain that the process of expansion is not at an end." ${ }_{4}$

It is not uninstructive to trace the development of the national library concept in the case of the Library of Congress. In its earliest form it implied, in addition to the already established meanings of public ownership and public access, hardly more than the principle of comprehensiveness of collections, at least with respect to the publications of the country itself. The emphasis upon this meaning is apparent in the resolution adopted by the A.L.A. at its meeting in the Army Medical Library on Feb. I0, I88I :

Resolved: That the American Library Association of Librarians, assembled in annual

Ibid. conference in Washington, shares the conviction of the people of the United States of America, that the Library of Congress is emphatically the one national library, the only one in the country destined to the encyclopedic and universal in its comprehensiveness, like the goverment libraries of the Old World. ... .5

Two years previously, in a discussion of book selection for a national library, the librarian of the London Library had stressed this aspect of comprehensiveness. He emphasized that a national library should be first a monument of the literature of its own country and a repertory of the best samples of the literatures of other countries; and second a "school of instruction" in proportion to its completeness in literatures in all languages. ${ }^{6}$

The concept of comprehensiveness was of course not a novel concept even in the '7o's; it was emphasized then because it was not yet an accomplished fact; just as it is now being emphasized in Canada where it is not yet an accomplished fact. ${ }^{7}$

But at the same time there were stirrings of other uses for a national library. Basset Cadwallader, in 1877 , proposed that there should be established at the Library of Congress a central bureau for cooperative library purchasing, and for preparing a universal catalog with union catalog symbols. ${ }^{8}$

By 1896 the library's new building was approaching completion, and the joint committee on the library held hearings on its organization and functions. ${ }^{9}$ Two representatives of the A.L.A. appeared to testify,

\footnotetext{
5 A.L.A. Papers and Proceedings of the Fourth General Meeting $188 \mathrm{r}$. p. $73 \mathrm{f}$.

'Library Journal 2: 1945, November-December 1877. "Davis, J. Basset. "A National Library for Canada." Ontario Library Review 2: 107 , May 1918.

Libraries in Canada-A Study of Library Conditions and Needs by the Commission of Enquiry. Chi-

cago, American Library Association, 1933. Ky Nary for Canada." Ontario Library Review 23: 181, May 1939. Canadian Library Council. Library Service for Canada, n. p., 1944, p. 9 .

Scollard, R. J." "Cataloguing for the Nation. Canadian Library Association. Proceedings of the Organizational Conference. 1946, p. 21.

8 Library Journal I: 364,369 , June 1877.

${ }^{9} 54$ th Congress, 2d Session, Senate Report ${ }_{5} 5 I_{3}$.
} 
as well as George Baker of Columbia, William Fletcher of Amherst, Samuel Langley of the Smithsonian Institution, and W. T. Harris, the U. S. Commissioner of Education; in addition, Melvil Dewey, Ainsworth Spofford, and Herbert Putnam, then librarian of the Boston Public Library. Here was an ideal occasion for a ringing statement as to the functions to be expected of a national library. Actually, however, the great need of the moment was to devise a form of organization and administration for the great new building; and the task immediately at hand was to transfer the immense collections from the Capitol to the new structure, and to get them into order and use. Nevertheless, buried in the discussion of the housekeeping details, may be found solid proposals for national service which have not been much improved upon since. Melvil Dewey described, in almost exact prediction, the distribution of printed catalog cards. He mentioned reference and copying services, distribution of government publications, the preparation of annotated selective bibliographies, a union catalog, and interlibrary loans. Dr. Putnam suggested, as additional appropriate functions, a clearing house for international exchanges, and influence toward standardization in indexing and bibliographic work.

By I 90 I the library was well-established in its new building and in its renovated tasks. On July 4 of that year Dr. Putnam, by then Librarian of Congress, addressed the Waukesha Conference of A.L.A. on "What May Be Done for Libraries by the Nation." ${ }^{10}$ Therein he forecast almost everything that was to be accomplished during his administration of the library: the work in cataloging and classification, the availability of specialists to answer inquiries, a union catalog, cooperative bibliographical

${ }^{10}$ A.L.A. Papers and Proceedings of the $23 d$ Meeting. 1901. p. 9 ff. undertakings (such as the A.L.A. Catalog, 1904, and the A.L.A. Portrait Index, I906), clearing house for duplicates and interlibrary loans. But the overwhelmingly important announcement made at the Waukesha Conference was that L.C. was printing cards, and might soon be able to make them available to other libraries.

The next forty years added nothing new to the concept of the national library function in the United States; the interval was filled with the execution of the plans of I 896 and I90I, and the only elaboration was in the specification of that all-inclusive term, "cooperative bibliographical undertakings." In 1938, however, appeared Carleton Joeckel's study of library service prepared for the Advisory Committee on Education which had been asked by President Roosevelt in 1937 to study the general relationship of the federal government to education. Dr. Joeckel, after noting four principal defects in the federal library machinery, expressed the opinion that "comparatively small increases in current expenditures would result in relatively large increases in the efficiency of the present bibliographical and technical operations." His recommendations included, among other things, the improvement and expansion of the cataloging and classification services of the Library of Congress to the full extent of their potential usefulness to American libraries of all types (italics mine), and mentioned several ways in which this should be done; he recommended the organization at the library of a national center for bibliographical information; and, finally, he suggested that a survey of the needs for regional library service, formulation of plans for giving such service, and the administration of a regional library system be conducted under the general direction of the Librarian of Congress. ${ }^{11}$

11 Joeckel, Carleton I3. Library Service. Washington, Government Printing Office, 1938. p. $33 \mathrm{f}$. 
In 1939 Dr. Robert C. Binkley, chairman of the joint Committee on Materials for Research of the American Council of Learned Societies and the Social Science Research Council, developed a national acquisitions program involving a radically new conception of the role of the national library. ${ }^{12}$ Proceeding on the assumptions that "acquisition policy is directed toward maximum national completeness," and that the acquisition policy of the Library of Congress should be one that would encourage cooperation on the part of other libraries toward attaining this goal of completeness, Dr. Binkley suggested methods for this, including the purchasing by the library of all current foreign books, or, alternatively, of all current foreign books not purchased by other libraries. Although these suggestions were not adopted, they went into the melting pot out of which the Farmington Plan later issued.

In 1945 the joint Committee on Indexing and Abstracting in the Major Fields of Research, representing the A.L.A. and nine other library and professional organizations, which since 1937 had been wrestling with the problem indicated by its title, rendered a final report. ${ }^{13}$ It recommended that the federal government take responsibility for the preparation of a general indexing and abstracting program which would include all fields of research; that the working unit which should execute the program should be operated in but not necessarily by the Library of Congress; and that the program should be supported by government subsidy as well as by the societies and associations which would benefit from it.

In the same year the director of the Office of Scientific Research and Development (Dr. Vannevar Bush) in his report to the President entitled Science, the Endless

12 Memorandum, November 27, rg39. $A$ National Acquisition Policy. Typescript. $\mathrm{L}$. C. files.

is A.L.A. Bulletin 39: 370-71, Oct. I5, 1945.
Frontier, ${ }^{14}$ suggested that existing government agencies, such as the Army Medical Library and the Library of Congress, could do much to improve existing bibliographic facilities if provided with sufficient means; and that federal aid for the library system of the country might well have as its central objective the strengthening of the Library of Congress so that it could foster programs of cooperation.

Still in 1945 it was found to be in the national interest that the Library of Congress should extend to other research libraries its own facilities for acquisition (including State and War Department channels) in countries where commercial channels were not available as a result of the war. At the same time the library commenced, on its own initiative and at its own cost, the program of document distribution which has since developed into the Documents Expediting Project.

In 1946 the Princeton Conference on International Cultural, Educational, and Scientific Exchanges directed four of its twenty-four recommendations toward the Library of Congress-recommendations having to do with the completion of the union catalog, the compilation of a union list of wartime periodicals, the preparation of plans for a national bibliography, and the procurement and distribution of foreign governmental publications. ${ }^{15}$

The latest statement on the subject is still fresh from the press, and is being reprinted in the 1947 annual report of the Librarian of Congress. The House Appropriations Committee, in 1946, had reported a reduction in the library's estimates, partly as it stated, in order "to give attention to the need for a determination as to what

\footnotetext{
14 Washington, Government Printing Office, 1945, p. II ${ }^{2}$. Recommendations Adopted by Conference on International, Cultural, Educational, and Scientific Exchanges.. - Chicago, American Library Associa. tion, r 947 .
} 
the policy of the Library of Congress is going to be in the way of expansion and service to the public and to Congress." In order to provide a basis for the discussion of this question, Dr. Evans appointed the Library of Congress Planning Committee, headed by the director of libraries of Harvard University, and consisting of leaders in various walks of life-the law, the humanities, specifically history, research libraries, public libraries, federal libraries, the natural sciences and bibliography. This committee was requested to review anew, "in a spirit of free inquiry," the role of the library, and to report recommendations which might be laid before the appropriate committees of Congress.

The report is now before Congress awaiting action. It spells out the relations of the library in the federal system; it specifies the kinds of collections which the library should amass. With respect to the relationships with nonfederal libraries and with the public the report states that "the $\mathrm{Li}$ brary of Congress as the National Library and as the largest and most nearly complete of all the libraries in the United States, should supplement the other libraries in the country, should take a leading part in cooperative movements among libraries, and should thereby help to bring about satisfactory nationwide library service to research workers and other seekers for information." Specifically "as its share of the national library program," the committee recommended a long list of services so carefully worded that it would be unfair to attempt to abridge them here; these include not only most of the services mentioned in previous discussions, but added certain new ones, such as "the printing at regular intervals of as complete a list as possible of publications currently issued in the United States," and a program of traveling exhibits.
It is apparent from the foregoing that if the library wants ambitions, it has not far to seek. But I refuse to call these objectives the ambitions merely of the Library of Congress. If they are not the ambitions of the American library world, and if the American library world cannot truthfully declare, as it did in $188 \mathrm{I}$, that with respect to these objectives "it shares the conviction of the people of the United States of America," then the Library of Congress may properly disown these ambitions. Let me give you the status of the more important of them.

\section{Ambitions-Present Posture}

In matters relating to bibliographical organization, the fundamental operation is still the system of card distribution. There is still much work to be done. Cards are not printed quickly enough, and they are still far from complete in coverage. While we are busily cataloging the publications of foreign countries, their libraries are busily cataloging ours. The cooperative cataloging operation, though contributing to the usefulness of the system, does not rest upon a sound policy either in logic or finance.

But card distribution, though in many senses fundamental, is itself an end-product; it is made possible by a number of antecedent operations-among them those of cataloging and classification. When we say at L.C. that we catalog and classify primarily for our own uses we are stating a policy to guide immediate operations only. In the long run it is hardly the fact. The proof of this is that we are involved up to our ears in the revision of the A.L.A. catalog code; and with respect to classification-we have recently witnessed the expenditure of a large sum, which will be matched over and over by expenditures into the indefinite future, in the elaboration of a new schedule for medicine, simply because the L.C. schedule had not been sufficiently 
well-adapted to changing conditions. And, too, we feel some concern at complaints regarding the incompletion of the law schedule. The truth is, that if L.C.'s card distribution is important, its cataloging and classification processes are also important.

The union catalog is increasing at the rate of a third of a million new titles and a million and a quarter new locations a year; to this work many libraries are contributing. We still talk of a subject union catalog. How badly is it wanted? The Cadwallader recommendation of 1877 for a universal catalog with union symbols (which was slapped down editorially as being too utopian in the issue of the Library Journal in which it appeared) is matched in 1947 by a suggestion for a union location index, by L.C. card number, to the Edwards Brothers or the L.C. Cumulative Catalog-a simple device which would bring a large part of the national union catalog, in a few volumes, into every library.

We have not taken up Dr. Joeckel's suggestion that the Librarian of Congress should administer a system of regional library centers; nor does it seem likely, from our policy of avoidance of executive authority, that we shall do so. But we are anxious to cooperate with regional centers.

It has been suggested that L.C. maintain the Union List of Serials. It is proposed that we take over the editing of the $W$ ritings on American History. It is recommended that we issue complete lists of current publications in the United States; that we submit plans for the national bibliography; that we engage in indexing and abstracting. Here caution is needed. The work to be done is infinite, and the criterion as to what may appropriately be done is not too clear. We now issue the Catalog of Title Entries of the Copyright Office, the Monthly Checklist of State Publications, the Cumulative Catalog of Library of Congress Printed Cards, all fragments (some of them rather large fragments) of the national bibliography. We do some indexing, some annotation of select lists, little abstracting. We are anxious to study the problem, because we have as much stake in the outcome as any institution, and more than most. We are ambitious to see the problem solved, but not necessarily to execute the solution. Some of you may have seen $\mathrm{Mr}$. Vanderbilt's memorandum on this subject which was distributed at the San Francisco Conference of A.L.A. last summer. ${ }^{16}$ At the present moment we are anxious to get discussion and comment on this memorandum.

In matters relating to acquisitions, I remind you again that the collections are historically and operationally (though not necessarily logically) at the basis of all the services, and that any proposal for bibliographic activity assumes in the first place that collections are available and organized. Consequently, the library world that is interested in our cards, our cataloging or our classification must be interested also in our collections. There may be alternatives, but they are not yet within practicable reach. Yet the Farmington Plan was born out of discussions in the Librarian of Congress' Council; we are anxious to see the proposal pushed to a conclusion even though we are not at all certain what that conclusion will be. But we are convinced that leadership is in the right hands; and the forces of economics, if nothing else, will assure a final determination. As to a distribution center for duplicates and foreign documents, this is one of the few suggestions dating from 1896 and I90I which has never been fully developed. The approaching dissolution of the American Book Center as a rehabili-

\footnotetext{
16 Vanderbilt, Paul. "National Bibliography and Bibliographical Control." [Washington] I947. Included in this issue of College and Research Libraries, together with comments by a bibliographer and two together with
librarians.
} 
tation agency provides the occasion for at least an experimental project to show possibilities. We are willing to assume a risk.

In connection with all of the foregoing, I wish to underscore several assumptions basic to any ambitions which L.C. may cherish: it has no wish to police or administer; it wishes to do nothing that others can do better; it wishes to take on no function which cannot be fully justified on grounds of economy, efficiency, and the national interest. The federal government cannot be looked to as a fairy godmother to take on projects merely because they are good and cannot be supported commercially or locally.

\section{The Public Interest and the Interested Public}

A parting word-the public interest will be served, in the long run, only as a result of the interest of the public. This is certainly true with respect to the services of a national library. Take a ready example, again the card distribution system-a system in the efficient operation of which most of you have a close interest. Last year L.C. sold, for $\$ 635,000$, the immense quantity of $19,000,000$ printed cards, each of which represented work in cataloging and classification amounting to from $\$ 2$ to $\$ 5$. (I leave you to calculate the potential value of these $19,000,000$ cards to their purchasers.) The receipts of $\$ 635,000$ actually more than reimbursed to the U.S. Treasury the cost of the overrun and of distribution.

In anticipation of a still greater demand for the cards during the present years we requested a "cushion" of working capital, which would not be used unless needed, and which-if used-would be similarly reimbursed through sales. The cushion was not appropriated. As things stand, sales are running 37 per cent over last year, but, for lack of this cushion, we have fallen two weeks behind in the execution of card orders, and will probably fall even further behind as the year progresses.

Cause and effect are very evident in this operation; but they work just the same way in all the underlying operations of cataloging, maintenance of classification schedules, and formation of collections; and if card distribution is of interest and of community importance, so are they.

Three presidents of the United States have felt the position of the Library of Congress in the national economy of sufficient moment to justify mention of it in annual message to Congress. I have already quoted from President Hayes. Let me quote from President Theodore Roosevelt's message of Dec. 3, 190I.

There are now over five thousand libraries in the United States, the product of [the past 50 years]. In addition to accumulating material, they are also striving by organization, by improvement in method, and by co-operation, to give greater efficiency to the material they hold, to make it more widely useful, and by avoidance of unnecessary duplication in process to reduce the costs of its administration.

In these efforts they naturally look for assistance to the Federal library, which though still the Library of Congress, and so entitled, is the one national library of the United States.... This library has a unique opportunity to render to the libraries of this country - to American scholarship-service of the highest importance. Resources are now being provided which will develop the collection properly, equip it with the apparatus and service necessary to its effective use, render its bibliographic work widely available, and enable it to become, not merely a center of research, but the chief factor in great cooperative efforts for the diffusion of knowledge and the advancement of learning.

To be "the chief factor in great cooperative efforts." That might well be the ambition of any institution! But, in this phrase I would underline the word "cooperative." 